\title{
DIFFERENCES IN LIFE HISTORY TRAITS OF RELATED EPILOBIUM SPECIES: CLONALITY, SEEd SIZE AND SEED NUMBER
}

\author{
Jürg Stöcklin \\ Institute of Botany, University of Basel, Schönbeinstr. 6, CH-4056 Basel, Switzerland; \\ tel. +41612673501, fax +41612673504,E-mail stoecklin2@ubaclu.unibas.ch
}

Keywords: Adaptation, Clonal growth, Morphology, Onagraceae, Reproduction, Root buds, Seed dispersal

\begin{abstract}
Small changes in morphology can affect the performance and functions of organisms and hence their ecological success. In modular constructed plants, contrasting growth strategies may be realized by differences in the spatial arrangement and size of shoots. Such differences change the way in which meristems and resources are assigned to various functions during the lifespan of a plant. If such changes include the capacity to spread clonally, sexual reproduction may also be affected. I compare patterns in vegetative growth and sexual reproductive traits in four allopatric species of Epilobium which are sometimes considered as subspecies of a single polymorphic taxon. The four species differ in the location of the buds which annually renew the aerial shoot system. E. dodonaei and E. steveni do not spread clonally and are characterized by a shrub-like habit. E. fleischeri, a species occurring only in the Alps, and E. colchicum, which occurs in the upper region of the Caucasus mountains, both produce buds on horizontal roots or plagiotropic shoots. Both alpine species exhibiting clonal growth have smaller shoots, fewer fruits and smaller seeds than the lowland species. An intraspecific trade-off between seed number per fruit and seed mass is realized. Both alpine species produce more seeds per fruit at the expense of seed mass. The morphological relationship between the four species and their geographical distribution suggest that clonal growth in E. fleischeri (restricted to the Alps) and E. colchicum (restricted to the Caucasus) is adaptively associated with the stressful conditions of alpine habitats. Our results suggest that clonal growth is not necessarily correlated with reduced reproduction by seeds. The success of plants which are already established may largely depend on clonal spread, but the colonization of new habitats depends on the production of a large number of small seeds with high dispersability.
\end{abstract}

\section{INTRODUCTION}

Fitness depends on successful reproduction. In plants with modular growth characteristics, reproduction may be achieved either sexually, by the production of seeds, or clonally, by the production of new potentially independent, but genetically identical ramets (HARPER 1978). There is a consistent association between the specific architectural structure of a plant and the way in which meristems and resources are committed to various functions during its lifespan (HARPER \& BeLl 1979, WATSON \& CASPER 1984, WALlER 1988, HUTCHINGS \& MOGIE 1990, DE KroON \& SCHIEVING 1990, KLIMEŠ et al. 1997). Life history theory predicts the existence of various trade-offs associated with reproductive traits. The amount of resources that can be invested either for sexual or for vegetative reproduction is limited, and thus a trade-off between the two modes of reproduction may be expected (SCHAFFER \& GADGIL 1975, WATSON 1984, SUTHERLAND \& VICKERY 1988). Essential life history traits are affected, depending on how this trade-off is resolved. For example, resources can be invested in new shoots and clonal expansion. Depending on the size and spatial arrangements of shoots, either 
the competitive strength of a genet (densely packed shoots, a "phalanx" strategy) or the colonizing ability (new shoots are placed far away, a "guerrilla" strategy) are more favoured (Lovett Doust \& LovetT Doust 1982, Sackville Hamilton et al. 1987). On the other hand, plants may invest resources to produce fruits and seeds. Seed yield of plants is affected by many factors, but the availability of resources (i.e. size related effects) are of great importance (SHIPLEY \& DION 1992). A major trade-off concerns the number and size of seeds (LLOYD 1987). Small seeds can be produced in large numbers, which favours dispersal, or resources can be invested in fewer but larger seeds with better chances of successful establishment under competition or abiotic stress. Furthermore, clonality and sexual reproductive behavior may be associated. ERIKSSON (1992) has suggested that clonal growth may have been selected more frequently in lineages with seeds adapted for long-distance dispersal. For local dispersal a plant can propagate clonally or use seeds. The success of a plant already established may largely depend on its capacity for horizontal clonal spread, but the colonization of new habitats depends mostly on the dispersal ability of seeds. Thus, life history traits, such as the ability to spread clonally, and seed size and number, may not evolve independently from each other.

Here, I compare patterns in vegetative growth and sexual reproductive traits in four allopatric species of Epilobium L. which are sometimes considered as subspecies of a single polymorphic taxon. Two of the species have a high altitude distribution and experience repeated disturbance in their respective habitats. The main objectives of this study are to use intraspecific patterns of reproductive attributes to demonstrate that (1) the occurrence of clonal growth within this group is related to habitat, and (2) that seed size and number is related to growth form, with clonal species having smaller, more numerous seeds with a better dispersability.

\section{THE PLANT SPECIES}

Epilobium dodonaei VILL., E. steveni BoISS., E. fleischeri HocHST. and E. colchicum ALBOV (including E. caucasicum (HAUSSKN.) SOSN. ex GROSSH.) are closely related perennial herbs which colonize open habitats. Epilobium sect. Chamaenerion subsect. Rosmarinifolium (TACIK) P.H. RAVEN consists exclusively of these four species which, according to RAVEN (1976), could be regarded as subspecies of a single polymorphic taxon.

The four species differ in their geographical and altitudinal distribution and are largely allopatric (RAVEN 1962, RAVEN 1976, MeUSEl et al. 1965, SHISHKIN \& Bobrov 1974, Tab. 1). $E$. dodonaei, a European species, is usually found at altitudes below $1000 \mathrm{~m}$ and has the widest distribution, occurring from France to W Ukraine and the Caucasus. E. fleischeri is found only at altitudes above $1000 \mathrm{~m}$ and is restricted to the European Alps. E. steveni is a rare taxon found in semiarid mountain plains and dried gravel river beds. It is restricted in its distribution to eastern Turkey, Trans-Caucasia and northern Iran. E. colchicum is a Caucasian species usually found above $1900 \mathrm{~m}$.

Nothing certain is known about the evolution of this group. E. fleischeri was originally considered as a variety of $E$. dodonaei by HAUSSKNECHT (1884) and later gained the status of a subspecies (SCHINZ \& KELLER 1923). Naturally, hybrids between the two species, which replace each other altitudinally in the Alps, have occasionally been reported and THEURILLAT (1979), in a biosystematic study, artificially obtained fertile hybrids and proposed to reinstate $E$. fleischeri as a subspecies of $E$. dodonaei. Inspection of specimens in the Herbarium of the Institute of Botany of the Georgian Academy of Science in Tbilisi (Georgia) suggests that between $E$. dodonaei and $E$. colchicum natural hybrids may occur occasionally (J. STÖCKLIN, 
Table 1. Geographical and altitudinal distribution of Epilobium dodonaei VILL., E. steveni BoISS., E. fleischeri HOCHST. and E. colchicum ALBOV (Onagraceae, sect. Chamaenerion). Information from RAVEN (1962), MEUSEL et al. (1965), SHISHKIN \& BOBROV (1974).

Species

Geographical distribution

Altitudinal distribution (m)

E. dodonaei

Submediterranean and Carpathian European species which reaches its eastern limits in Turkey, the Caucasus and Persian Kurdistan

$300-900(-1400)$

E. fleischeri Subalpine and alpine zones of the Alps; in the inundation zone of alpine rivers, on moraines; one of the first and most abundant pioneers on the perimeter of glaciers

$1000-2400(-2700)$

E. colchicum

A subalpine and alpine species of the Caucasian mountains, in Turkey only in the mountains of Lazistan; on scree slopes and pebble beds, on moraines and on the perimeter of glaciers

$(900-) 1800-2800$

E. steveni

Eastern Turkey, Trans-Caucasia (Georgia), Northern Iran; on gravelly slopes and especially on dried up gravel river beds

$900-2000$

unpubl. obs.). Today, however, the four taxa are mostly thought to be distinct species (TUTIN et al. 1968, SHISHKIN \& BOBROV 1974).

All four species renew their aerial shoot system annually from subterranean buds to form adventitious shoots. Flower, fruit and seed morphology are similar, but shoots, inflorescences and seeds differ in size and number (RAVEN 1962, STÖCKLIN \& FAVRE 1994). Flowers are slightly zygomorphic and purplish, with entire but unequal petals. The style is pubescent in its lower part with a 4-lobed stigma. Seeds are papillose with a tuft of long trichomes at the chalazal end that aids in dispersal. Their different modes of annual shoot renewal and different growth form have never been considered when classifying these species. However, STÖCKLIN (1992) and STÖCKLIN \& FAVRE (1994) have shown that E. dodonaei and E. fleischeri are clearly distinct in vegetative growth and reproductive behaviour.

\section{METHODS}

I examined the morphology, the ability of clonal expansion, population structure, and traits of shoots, flowers, fruits and seeds at natural sites: Epilobium dodonaei and E. fleischeri in Switzerland, and E. colchicum and E. steveni during a study visit in the Caucasus (Georgia). E. fleischeri was investigated on the perimeter of the Rhone- and Morteratsch glacier in the Central Alps (1750 and $1900 \mathrm{~m}$, respectively). E. dodonaei was investigated on the flood plains of the Maggia near Someo in the Ticino, Switzerland $(380 \mathrm{~m})$ and at ruderal sites in Pratteln and Huninque in the close surroundings of Basel, Switzerland $(280 \mathrm{~m})$. E. steveni was investigated in Georgia, district Meskethi, on dry banks of the river Kura, near Vardzia $(1400 \mathrm{~m})$ and on flood plains of the same river south of Borshomi $(950 \mathrm{~m})$. E. colchicum was investigated in Georgia, district Abkhazeti, on banks of the river Auadchara (1700 m), district Khevi, on moraines of the Deodoraki glacier $(2300 \mathrm{~m})$, near the village Kasbeghi $(1900 \mathrm{~m})$, and in the same district on river banks between Sno and Achalziche $(1850 \mathrm{~m})$. For 10 individuals in each field population I measured: the size of clones, height of shoots, number of sexual meristems (flowers) per inflorescence, length of fruit, length and width of leaf, 
Table 2. List of quantitative characters used for comparison between Epilobium dodonaei, E. steveni, E. colchicum and E. fleischeri. Values are means ( \pm s.d.) from measurements in the field of $c a$. 30 individuals from several populations of each species.

\begin{tabular}{lcccc} 
Character & E. dodonaei & E. steveni & E. colchicum & E. fleischeri \\
\hline Height of shoots $(\mathrm{cm})$ & $72 \pm 26$ & $69 \pm 13$ & $39 \pm 13$ & $15 \pm 7$ \\
Flowers per inflorescence & $31 \pm 12$ & $38.3 \pm 13$ & $14 \pm 5$ & $11 \pm 4$ \\
Length of fruit $(\mathrm{mm})$ & $71 \pm 7$ & $62 \pm 8$ & $61 \pm 8$ & $52 \pm 9$ \\
Length of leaf $(\mathrm{mm})$ & $47 \pm 7$ & $40 \pm 7$ & $37 \pm 8$ & $26 \pm 5$ \\
Width of leaf $(\mathrm{mm})$ & $2.1 \pm 0.4$ & $4.0 \pm 0.7$ & $6.4 \pm 1.8$ & $4.6 \pm 1.3$ \\
Ratio length/width of leaves & $22.6 \pm 2.8$ & $10.2 \pm 1.7$ & $5.9 \pm 1.2$ & $5.8 \pm 1.0$ \\
Length of sepal $(\mathrm{mm})$ & $12.9 \pm 1.1$ & $12.2 \pm 1.6$ & $13.7 \pm 1.4$ & $14.2 \pm 1.8$ \\
Width of sepal $(\mathrm{mm})$ & $2.2 \pm 0.2$ & $1.9 \pm 0.3$ & $2.8 \pm 0.4$ & $2.8 \pm 0.4$ \\
Length of petal $(\mathrm{mm})$ & $16.5 \pm 1.5$ & $14.7 \pm 2.2$ & $18.0 \pm 2.2$ & $15.5 \pm 1.9$ \\
Width of petal $(\mathrm{mm})$ & $7.5 \pm 0.7$ & $7.5 \pm 0.8$ & $9.5 \pm 1.4$ & $8.4 \pm 1.7$ \\
Ovules per fruit & $104 \pm 13$ & $108 \pm 16$ & $154 \pm 19$ & $135 \pm 26$ \\
Seed mass $(\mu \mathrm{g})$ & $344 \pm 59$ & $285 \pm 41$ & $210 \pm 37$ & $132 \pm 33$ \\
\hline
\end{tabular}

sepal and petal, mean number of ovules per fruit, and mean seed mass. Furthermore, the following qualitative traits with their character states were examined: pubescence of leaves, form of style, clonal growth strategy, i.e. the capacity of horizontal spread of clones, and seed colour. For a visual representation of the overall similarity among species a principal component analysis based on vegetative and reproductive traits in ca. 30 individuals of each species was performed using GENSTAT (PAYNE 1993) and for each individual the principal component scores of the two first axes were plotted. In addition to field measurements, several plants from each of the four species were grown in the greenhouse from seeds collected from field sites and replanted in normal garden conditions. However, the data presented here are from measurements made in the field.

\section{RESULTS}

\section{Overall similarity}

The morphology of shoots, flowers and fruits is very similar and differences between the four species are mostly quantitative (Tabs. 2 and 3). Exceptions to this include: in E. fleischeri the style is bent backwards and in the other species the style is straight. E. steveni is usually canescent throughout with appressed strigulose pubescence and the other species are glabrous or sparsely pubescent. However, sparsely pubescent plants occurred occasionally also in populations of $E$. steveni. Leaves differ in size but especially in their shape. The ratio of length/width of leaves is much higher in $E$. dodonaei and $E$. steveni compared to the two alpine species. Noticeable differences are the colour of seeds and the clonal growth strategy.

In all species the size and number of shoots is dependent on the age of individuals and is highly variable. There are marked differences in shoot and inflorescence size among species (Tab. 2). E. dodonaei and E. steveni have large shoots of similar size and may produce more than 30-40 fruits in a single elongated inflorescence. Both alpine species have much smaller shoots with 10-15 fruits on short, nearly corymbous inflorescences. E. fleischeri has the smallest shoots of the four species.

Ordination from principal component analysis (Fig. 1) clearly separates the two species of lower altitudinal distribution from both alpine species. There is a large overall similarity 


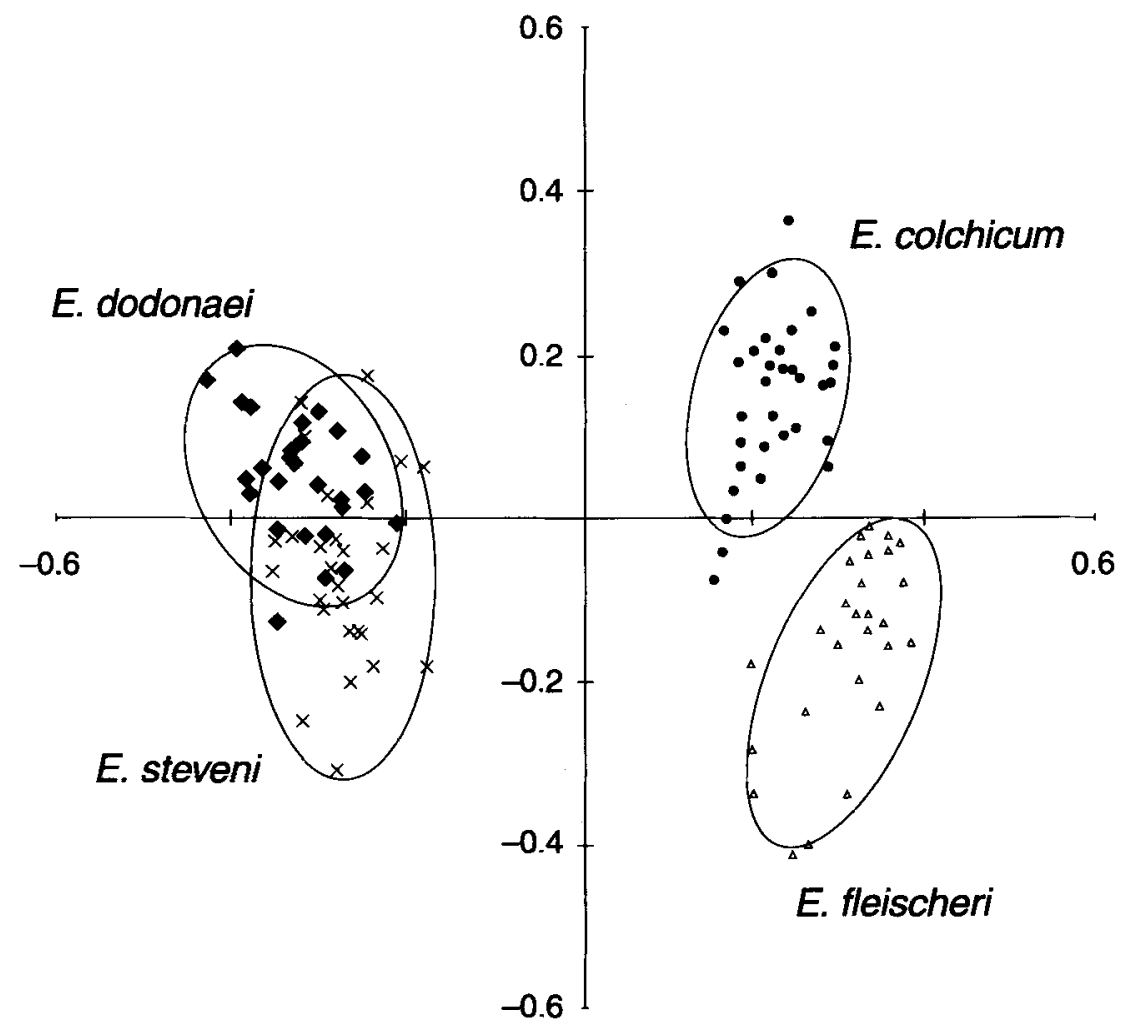

Fig. 1. Plot of scores from the first two axes of a principal component analysis based on morphological and reproductive traits from shoots of four allopatric species of Epilobium. The analysis is based on a correlation matrix of quantitative measurements of ca. 30 individuals in natural sites of several populations of each species. All characters used were equally weighted. The first axes explains $56 \%$ and the second axis explains $16 \%$ of the variation among shoots. Ellipses are $95 \%$ confidence limits with scores from shoots of the four species calculated separately. Characters used are listed in Tabs. 2 and 3.

between the two taxa from lower altitudes ( $E$. dodonaei, $E$. steveni). Overall differences between these two species and the two alpine species (E. fleischeri, E. colchicum) and between the two alpine species are much larger.

\section{Growth form and clonal growth strategy}

All four species renew their aerial shoots annually from subterranean buds. Differences among species in the location of buds result in different growth strategies (Fig. 2).

The growth strategy of $E$. dodonaei and $E$. steven $i$ is very similar. Renewal of bud formation is restricted to the hypocotyl and in larger plants to the transitional region between root and shoot. Plants are shrub-like and have no vegetative mobility. Consequently, populations of the two species are composed of individual plants of different size and shoot number.

In E. fleischeri buds are located not only at the transitional region between root and shoot but in addition this species is able to exploit new areas by horizontal roots and the formation of shoots from root buds. This plant has a pronounced capacity to expand laterally. Diameter of genets is up to $2 \mathrm{~m}$ with a maximum spacing of ramets between $50-70 \mathrm{~cm}$. In this way, 

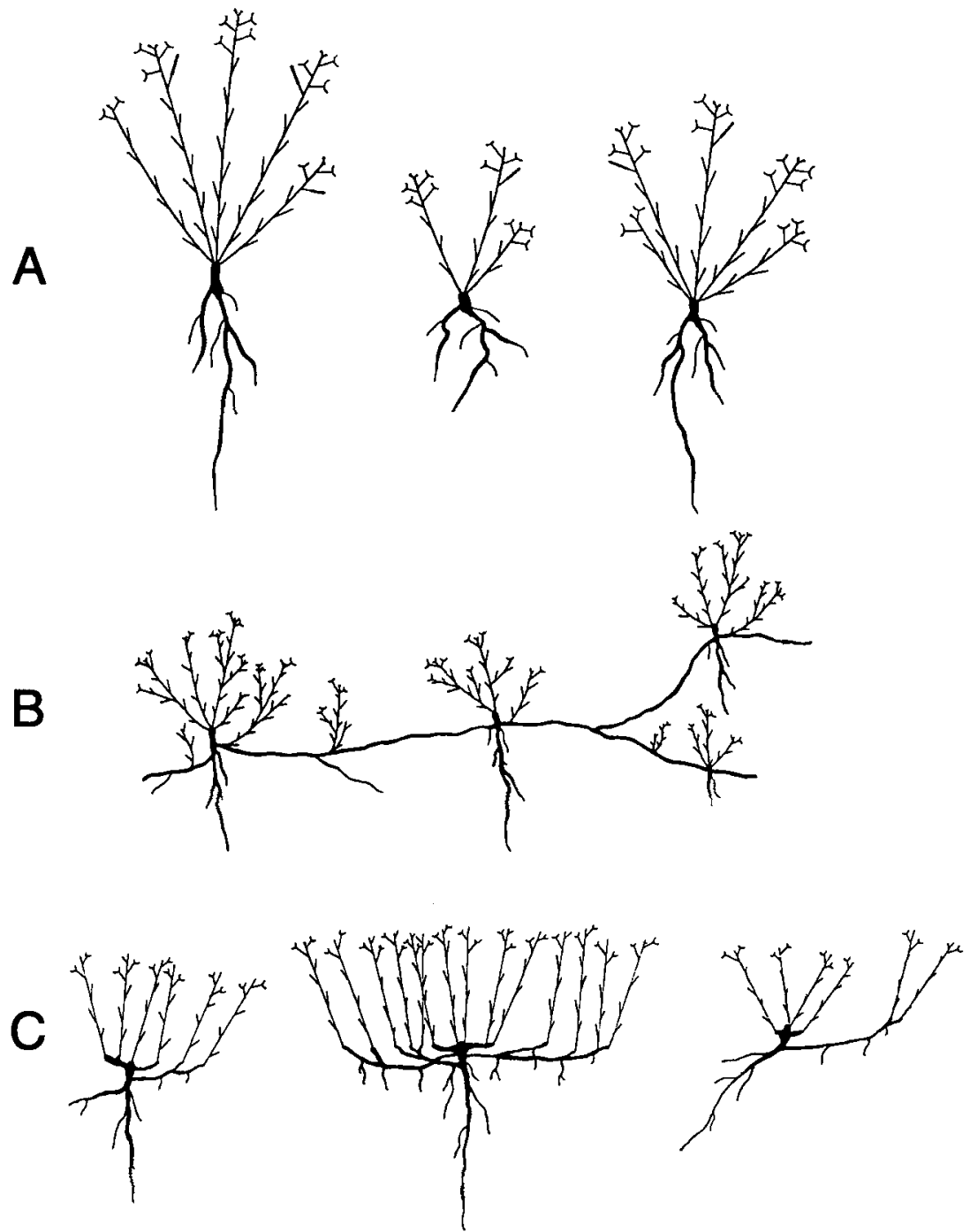

Fig. 2. Characteristic representation of growth form of 4 Epilobium species. A - Epilobium dodonaei and $E$. steveni (similar growth form for both species); B $-E$. fleischeri; $\mathrm{C}-E$. colchicum. Schematic drawings based on investigation of individuals at natural sites and from the experimental garden.

sites unsuitable for seedling establishment can be colonized and frequently genets are intermingled. As a consequence, populations of E. fleischeri consist of more or less compact clusters of shoots or even single shoots connected by long horizontal roots. Recolonization after heavy disturbance is rapid and fragmentation of genets is possible. In pioneer vegetation single shoots or small clumps of shoots prevail. Later during succession fewer, but larger clumps dominate. If competition from other species becomes important, small clumps or isolated single shoots again prevail.

Epilobium colchicum is characterized by a limited capacity to spread laterally. Plants produce shoots from a tap root and from the base of shoots which are not only oriented 

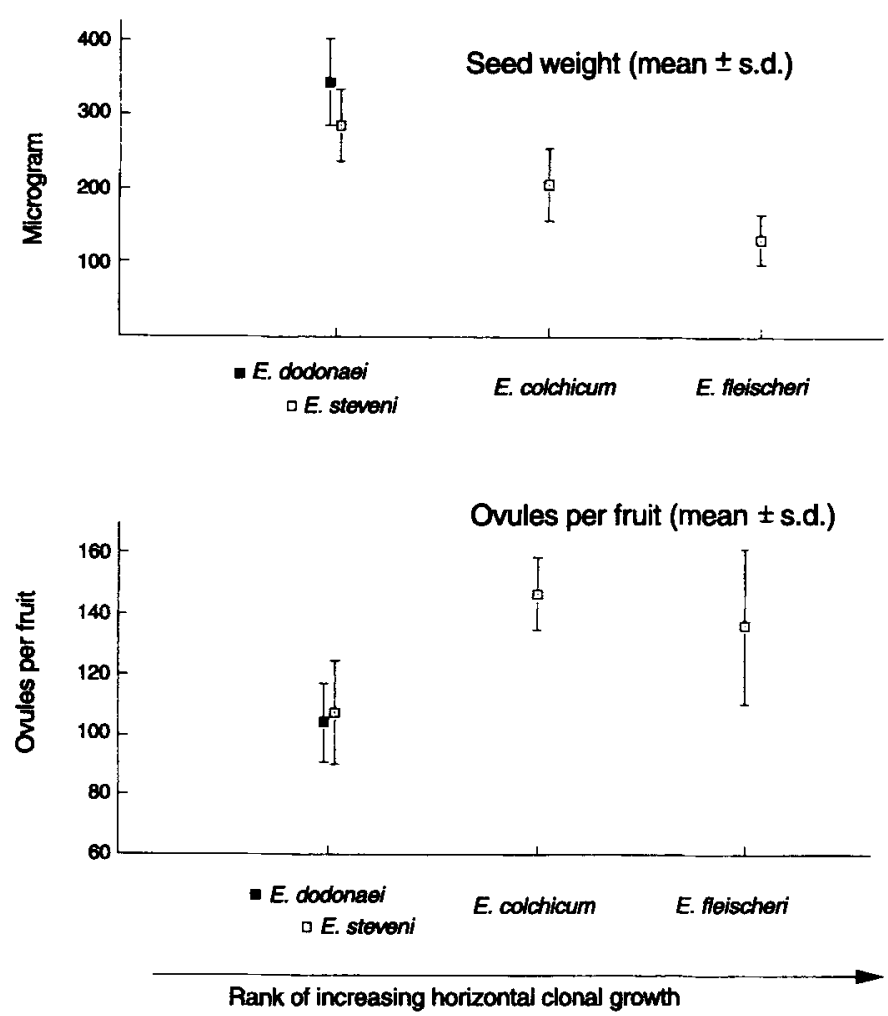

Fig. 3. Trade-off between seed mass and ovule number among Epilobium species. The two lowland species (E. dodonaei, E. steveni) without lateral clonal spread, and the two alpine species (E. colchicum, E. fleischeri) with the capacity of lateral clonal growth are ordered on the $x$-axis using an arbitrary scale of increasing clonality. Values are means with standard deviation bars from measurements of individual seeds $(n=100)$ and ovules per fruits $(n=30)$ from several individuals of each species.

orthotropically but sometimes plagiotropically as well. In this way, dense competitive clones may occur with a maximum diameter of up to $2 \mathrm{~m}$, but the maximum spacing of ramets is only $2-5 \mathrm{~cm}$. However, plants depend on their tap root and fragmentation of old clones does not occur. Sometimes, several somewhat isolated clusters of shoots are connected by short horizontal roots or plagiotropic rhizomes. In pioneer habitats with frequent disturbance a variable growth form results, and a loose cluster of shoots connected by roots or rhizomes occurs. However, long horizontal roots with buds were never observed and fragmentation of clones is unlikely.

\section{Seed size and number}

Fruits and seeds of all species are morphologically identical. Fruits open when they are dry and are distributed by wind. Between species, seed mass and ovule number differ consistently (Fig. 3). Mean seed mass is highest in E. dodonaei and decreases in the order $E$. steveni, E. colchicum and E. fleischeri. Conversely, the mean number of ovules is much lower in $E$. dodonaei and $E$. steveni compared to the alpine $E$. fleischeri and $E$. colchicum. Consequently, a trade off between seed number and seed mass occurs between species. With 
Table 3. List of qualitative characters with character states used for comparison between Epilobium dodonaei (E.d.), E. steveni (E.s.), E. colchicum (E.c.) and E. fleischeri $(E . f$. and their presence based on observations of ca. 30 individuals from several populations of each species. Codes within the table: $+=$ commonly present, $(+)=$ sporadically present, $-=$ not present; * see Fig. 2 and text for explanation.

Character and character states E.d. E.s. E.c. E.f.

Pubescence of leaves

- glabrous

- sparsely pubescent

- heavily pubescent

Form of style

- short, bent backwards

- long and straight

Clonal growth strategy *

- no clonal spread

- "phalanx"

- "guerrilla"

Seed color

- bright yellow

- brown

- dark red

$\begin{array}{cccc}(+) & - & + & + \\ + & (+) & - & - \\ - & + & - & -\end{array}$

$\begin{array}{cccc}- & - & - & + \\ + & + & + & - \\ + & + & (+) & (+) \\ - & - & + & - \\ - & - & - & +\end{array}$$$
-\quad+
$$$$
\begin{array}{rrrr}
- & - & - & + \\
+ & + & - & - \\
- & - & + & - \\
\hline
\end{array}
$$

increasing clonality between species seed mass is reduced and ovule number is increased. Results from an earlier study on fecundity regulation suggest that this trade-off contributes to a similar number of ripe seeds per shoot if $E$. dodonaei and E.fleischeri are compared (STÖCKLIN \& FAVRE 1994).

\section{DISCUSSION}

The comparison of vegetative growth strategies and sexual reproductive traits in closely related Epilobium-species revealed that the two low altitude species reproduce exclusively by seeds, and compared to the alpine species, they invest relatively more in seed size. On the other hand, both alpine species are able to colonize the close surroundings of already established plants by horizontal clonal growth. A preference of plants for clonal growth in cold, alpine or arctic habitats has been noted by several authors (SÖYRINKI 1938, Hartmann 1955, Callaghan \& Emanuelsson 1985, Callaghan 1988, KlimeŠ et al. 1997). However, in the case of the studied Epilobium-species, the ability of clonal reproduction is not correlated with a reduction in sexually produced seeds. Both high altitude species with clonal spread have smaller, more numerous and better dispersed seeds.

\section{Clonal spread by root buds}

Clonal growth, or vegetative reproduction, can occur by a multitude of organs and morphological types (ABRAHAMSON 1980). TIFFNEY \& NiKLAS (1985) proposed that the different means of clonal habit among dicotyledons are a derived condition and may have an independent origin. Buds on roots, as in Epilobium, are a scarce form of clonal growth but occur in species or genera of several plant families (RAUH 1937). So far, this mode of clonal growth has received relatively little attention even though it occurs in several conspicuous species (e.g. Cirsium arvense (L.) SCOP., Convolvulus arvensis L., Epilobium angustifolium L., Euphorbia cyparissias L., Linaria vulgaris Mill., Populus tremula L., Rumex acetosella L.). The significance of the clonal strategy in Epilobium fleischeri to its success on alpine glacial forelands has been addressed earlier (STÖCKLIN 1990, 1992, STÖCKLIN \& BÄUMLER 1996). In E. fleischeri root buds are placed all over the root system including on long horizontal roots. Glacial forelands are very heterogeneous in relation to available nutrients and moisture (JoCHIMSEN 1970, MATTHEWS 1992). In such an environment new shoots from root buds are occasionally placed in favourable sites and their growth is enhanced. Bare soil unsuitable for seedling establishment is colonized by horizontal roots and after major disturbances in the 
inundation zone of streams or on steep moraines quick recolonization by this plant is possible. Shoots from buds on horizontal roots combined with an opportunistic growth response results in a foraging strategy of $E$. fleischeri. In favourable and undisturbed conditions larger clumps of shoots may be formed. When vegetation is denser, clonal spread enables individuals to avoid competition by fugitive growth and isolated single shoots or small clumps of shoots prevail in later successional stages.

In E. colchicum a slightly different strategy is realized. Long horizontal roots do not occur and horizontal spread is limited. In undisturbed conditions dense competitive clones of large diameter are formed; in heavily disturbed habitats a loose cluster of shoots may develop. Morphologically, this growth strategy is intermediate between sessile clones and plants with a pronounced clonal mobility. Large clones of $E$. colchicum were observed in dense herbaceous vegetation, indicating a competitive strength not present in E. fleischeri. Nevertheless, in heavily disturbed sites this clonal strategy is functionally comparable to the strategy of E. fleischeri.

\section{Trade-off between seed mass and number}

The trade-off between seed mass and seed number among the Epilobium species studied is noteworthy. A standard expectation is that allocation to clonal reproduction implies a low sexual reproductive effort (SCHAFFER \& GADGIL 1975, ABRAHAMSON 1980). However, both alpine species with a clonal growth habit have smaller shoots and inflorescences, but produce more seeds at the expense of seed mass compared to the two lowland species. The large number of ovules per fruit in E. fleischeri and E. colchicum suggests a strong selection for a high seed set. Since resources for producing seeds are limited, a tendency towards smaller seeds would be expected unless selection for larger seeds is strong (WESTOBY et al. 1992). Seed mass is commonly correlated with seedling success, but in stressful alpine habitats the success of a plant may depend to a large extend on its capacity for clonal growth. Seedling establishment in such habitats depends more on the probability that a seed reaches a "safe site" than on the competitive ability of a seedling, i.e. its seed weight (URBANSKA \& SCHÜTZ 1986, STÖCKLIN \& BÄUMLER 1996). Horizontal spread by clonal growth guarantees the colonization of near-distance sites, and one could expect selection in clonal species to favour the production of more seeds that are dispersed over wider distances. ERIKSSON (1997) suggested that in species for which seedling recruitment occurs only in the early stages of population development, selection should favour small seed sizes and high fecundity that increase the chance of finding new suitable sites for colonization. Interestingly, in Epilobium angustifolium, a species with an even more pronounced ability to spread laterally (VAN ANDEL 1975 ) and belonging to the same section (Chamaenerion TAUSCH) of the genus, the trend for more numerous seeds at the expense of seed mass continues. E. angustifolium has 400-500 ovules per fruit and tiny seeds, three times smaller even than the seeds of $E$. fleischeri (pers. obs.). Thus, among related Epilobium species, clonal spread is associated with an increase in seed number and a decrease in their size, indicating a better dispersability. It cannot be excluded, though, that the observed correlation might arise as a result of covariation with some other unmeasured life history trait. Undoubtedly, the relationship between clonality and sexual reproductive traits deserves further investigations. 


\section{Evolutionary relationship}

Nothing certain is known about the phylogenetic relationship among the four taxa and all comparative analysis are open to alternative interpretations (REES 1993). However, some inferences can be made from our results. First, the common growth form and the close overall similarity suggest that $E$. steveni should rather be considered as a (rare) geographical race of the widespread $E$. dodonaei than as a distinct species. Second, the two allopatric species E. fleischeri (restricted to the Alps) and E. colchicum (occurring only in the Caucasus mountains) are descendants from the widespread $E$. dodonaei, a species without clonal spread. The morphologically slightly different clonal growth strategies of the two alpine species are adaptively associated to the stressful conditions of high mountain habitats and have probably been attained independently. This interpretation is supported by (a) the geographical distribution of the species which makes it unlikely that the endemic distribution of $E$. fleischeri and $E$. colchicum is a relict of a formerly continuous distribution, and (b) by the occasional occurrence of natural hybrids between $E$. dodonaei and E. fleischeri in the Alps, and $E$. dodonaei and $E$. colchicum in the Caucasus.

\section{CONCLUSION}

The results of this study suggest that clonal growth in plants must not necessarily be correlated with reduced reproduction by seeds as has been frequently assumed. Among related Epilobium-species clonal spread is combined with larger seed number at the expense of seed mass. Clonal growth may assure colonization of the surroundings of already established plants but not of new sites. In stressful alpine pioneer habitats clonal growth, in combination with a maximum number of small seeds, seems to be of particular advantage.

Acknowledgements: I gratefully thank G. Nakhutsrishvili from the Institute of Botany of the Georgian Academy of Science who invited me to work in Georgia. G. Sanadiradze, M.G. Kokaia, S. Adzinba and A. Chkikuadze guided my excursions to populations of Epilobium colchicum and E. steveni in Georgia: without their help this study would not have been possible. J. Arnone and three anonymous reviewers provided valuable comments to earlier drafts of this manuscript. This work was supported by the Swiss National Science foundation grant no. 3.631-0.87 and by the Treubel Fond of the Freiwillige Akademische Gesellschaft Basel.

\section{REFERENCES}

ABRAHAMSON W.G. (1980): Demography and vegetative reproduction. In: SOLBRIG O.T. (ed.), Demography and evolution in plant populations, Blackwell Sci. Publ., Oxford, pp. 89-106.

CALLAGHAN T.V. (1988): Physiological and demographic implications of modular construction in cold environments. In: DAVY A.H. et al. (eds.), Population biology of plants, Blackwell, Oxford, pp. 111-135.

Callaghan T.V. \& EMANUelsson U. (1985): Population structure and processes of tundra plants and vegetation. In: WHITE J. (ed.), The population structure of vegetation, Junk Publishers, Dordrecht, pp. 399-439.

DE KROON H. \& SCHIEVING F. (1990): Resource partitioning in relation to clonal growth strategy. In: VAN GROENENDAEL J. \& DE KROON H. (eds.), Clonal growth in plants: Regulation and function, Academic Publishing, The Hague, pp. 113-130.

ERIKSSON O. (1992): Evolution of seed dispersal and recruitment in clonal plants. Oikos 63: 439-453.

ERIKSSON O. (1997): Clonal life histories and the evolution of seed recrutiment. In: DE KROON H. \& VAN GroenENDAEL J. (eds.), The ecology and evolution in clonal plants, Backhuys Publishers, The Netherlands, pp. 211-226. 
HARPER J.L. (1978): The demography of plants with clonal growth. In: FREYSEN A.H.J. \& WOLDENDORP J.W. (eds.), Structure and functioning of plant populations, North Holland Publishing Company, Amsterdam, pp. 27-48.

HARPER J.L. \& BELL A.D. (1979): The population dynamics of growth form in organisms with modular construction. In: ANDERSON R.M. et al. (eds.), Population dynamics, 20th Symposium of the British Ecol. Soc., Blackwell, London, pp. 29-52.

HARTMANN H. (1955): Studien über die vegetative Fortpflanzung in den Hochalpen. PhD Thesis, Universität Zürich, Zürich.

HAUSSKNECHT C. (1884): Monographie der Gattung Epilobium. Jena.

HUTCHINGS M.J. \& MOGIE M. (1990): The spatial structure of clonal plants: control and consequences. In: VAN GROENENDAEL J. \& DE KROON H. (eds.), Clonal growth in plants: Regulation and function, Academic Publishing, The Hague, pp. 57-76.

JOCHIMSEN M. (1970): Die Vegetationsentwicklung auf Moränenböden in Abhängigkeit von einigen Umweltfaktoren. Veröff. Univ. Innsbruck 46: 5-22

KLIMEŠ L., KLIMEŠOVÁ J., HENDRIKS R. \& VAN GROENENDAEL J. (1997): Clonal plant architecture: a comparative analysis of form and function. In: DE KROON H. \& VAN GROENENDAEL J. (eds.), The ecology and evolution in clonal plants, Backhuys Publishers, The Netherlands, pp. 1-29.

LLOYD D.G. (1987): Selection of offspring size at independence and other size-versus number strategies. Amer. Naturalist 129: 800-817.

LovetT Doust L. \& LoveTT Doust J. (1982): The battle strategies of plants. New Sci. 8: 81-84.

MATTHEWS J.A. (1992): The ecology of recently deglaciated terrain. Cambridge studies in ecology, Cambridge University Press, Cambridge.

MEUSEL H., JÄGER E. \& WEINERT E. (1965): Vergleichende Chorologie der zentraleuropäischen Flora. Fischer, Jena.

PAYNE R.W. (1993): GENSTAT 5 reference manual. Clarendon Press, Oxford.

RAUH W. (1937): Die Bildung von Hypocotyl- und Wurzelsprossen und ihre Bedeutung für die Wuchsformen der Pflanzen. Nova Acta Leop. 24: 345-555.

Raven P.H. (1962): The genus Epilobium in Turkey. Notes Roy. Bot. Gard. Edinburgh 24: 184-203.

RaVEN P.H. (1976): Generic and sectional delimitation in Onagraceae, tribe Epilobieae. Ann. Missouri Bot. Gard. 63: 326-340.

REES M. (1993): Trade-offs among dispersal strategies in British plants. Nature 366: 150-152.

SACKVILLE HAMILTON N.R., SCHMID B. \& HARPER J.L. (1987): Life history concepts and the population biology of clonal organisms. Proc. Roy. Soc. London B 232: 35-57.

SCHAFFER W.M. \& GADGIL M.D. (1975): Selection for optimal life histories in plants. In: CoDY M.L. \& DIAMOND J. (eds.), Ecology and evolution in communities, Belknap Press, Cambridge, pp. 142-156.

SCHINZ H. \& KELLER R. (1923): Flora der Schweiz. Ed. 4. Zürich.

SHIPLEY B. \& DION J. (1992): The allometry of seed production in herbaceous angiosperms. Amer. Naturalist 139: $467-483$.

SHISHKIN B.K. \& BoBRov E.G. (eds.) (1974): Flora of the U.S.R.R. 15. Israel Program for Scientific Translations, Jerusalem.

SÖYRINKI N. (1938): Studien über die generative und vegetative Vermehrung der Samenpflanzen in der alpinen Vegetation Petsamo-Lapplands. I. Allgemeiner Teil. Ann. Bot. Soc. Zool. Bot. Fenn. Vanamo 11: 83-89, 124-147.

STÖCKLIN J. (1990): Populationsstruktur des Rohbodenpioniers Epilobium fleischeri HocHST. auf dem Morteratsch-Gletschervorfeld. Verh. Ges. Ökol. 19: 30-43.

STÖCKLIN J. (1992): Differences in the location of subcotyledonary buds among Epilobium angustifolium L., E. dodonaei VILL. and E. fleischeri HocHST. (Onagraceae) and effects on architecture and population stnucture. Bot. J. Linn. Soc. 108: 35-47.

STÖCKLIN J. \& BÄUMLER E. (1996): Seed rain, seedling establishment and clonal growth strategies on a glacier foreland. J. Veg. Sci. 7: 45-56.

STÖCKLIN J. \& FAVRE P. (1994): Effects of plant size and morphological constraints on variation in reproductive components in two related species of Epilobium. J. Ecol. 82: 735-747.

SUTHERLAND S. \& VICKERY R.K. (1988): Trade-offs between sexual and asexual reproduction in the genus Mimulus. Oecologia 76: 330-335. 
THEURILLAT J.-P. (1979): Etude biosystématique d'Epilobium dodonaei VILL. et d'E. fleischeri HochST. (Onagraceae). Bull. Soc. Neuchâteloise Sci. Nat. 102: 105-128.

TIFFNEY B.H. \& NIKLAS K.J. (1985): Clonal growth in land plants: a palaeobotanical perspective. In: JACKSON J.B., Buss L.W. \& CoOK R.E. (eds.), Population biology and evolution of clonal organisms, Yale Univ. Press, New Haven, pp. 35-66.

TUTiN T.G. et al. (eds.) (1968): Flora europaea 2. Cambridge University Press, Cambridge.

URBANSKA K.M. \& SCHÜTZ M. (1986): Reproduction by seed in alpine plants and revegetation research above timberline. Bot. Helv. 96: 43-60.

VAN ANDEL J. (1975): A study on the population dynamics of the perennial plant species Chamaenerion angustifolium (L.) Scop. Oecologia 19: 329-337.

WALLER D.M. (1988): Plant morphology and reproduction. In: LOVETT DOUST J. \& LOVETT DOUST L. (eds.), Plant reproductive ecology, Oxford University Press, New York, pp. 203-227.

WATSON M.A. (1984): Development constraints: effect on population growth and patterns of resource allocation in a clonal plant. Amer. Naturalist 12: 411-426.

WATSON M.A. \& CASPER B.B. (1984): Morphogenetic constraints on patterns of carbon distribution in plants. Annual Rev. Ecol. Syst. 15: 233-258.

WESTOBY M., JURADO E. \& LEISHMANN M. (1992): Comparative evolutionary ecology of seed size. Trends Ecol. Evol. 7: 368-372. 